\title{
Insecticidal potential of some plant extracts in nano and normal form on immatures stages of red palm weevil Rhynchophorus ferrugineus
}

\author{
Ali A.A.*, K.M. Mohanny, G.S. Mohamed and R.O.H. Allam \\ Plant Protection Department, Faculty of Agriculture, South Valley University, Qena 83523, Egypt
}

\begin{abstract}
Red palm weevil, $R$. ferrugineus (Coleoptera: Dryophthoridae) is the principal insect pest attacks date palm all over Egypt, Current work aims to take advantage of effective, ecofriendly, and safer plant sources in pest control. Toxicity of some plant crude extracts on both normal and nano form against eggs and larvae stags of RPW was assessed in laboratory exposure experiments. The treatments comprised three different concentration of plant extracts $(5,10$ and $15 \mathrm{mg} / 100 \mathrm{ml})$ for both normal and nano extracts of selected plants using aquatic solutions. Data showed that all the evaluated extracts showed potential ovicidal and larvicidal activity against RPW, nano extracts recorded the highest ovicidal and larvicidal activities compared to normal extract, as ovicidal potential eucalyptus nano extract at $15 \%$ was the most toxic which give $(80.00 \pm 1.00 \%)$ mortality, $\left(\mathrm{LC}_{50}=9.011\right)$ followed by oleander nano extract at $15 \% \quad 76.67 \pm 0.58 \% \quad\left(\mathrm{LC}_{50}=9.48\right)$ and Datura extract at $15 \quad(70.0 \pm 1.0 \%)$ $\left(\mathrm{LC}_{50}=9.652\right)$, while, in Larvicidal activity, nano eucalyptus was the highest effect among all extraction $\left(\mathrm{LC}_{50}=5.228\right)$ followed by Oleander $\left(\mathrm{LC}_{50}=6.042\right)$.
\end{abstract}

Keywords: Rhynchophorus ferrugineus; Plant extracts; Date palm; Nano extracts.

\section{Introduction}

Date palm is one of the strategic fruits in Egypt, where Egypt ranks first in the world in the production of dates (FAO, 2019). Dates production in Egypt and the world faces a group of insect and animal pests that reduce the quantity and quality. RPW, R. ferrugineus Olivier (Coleoptera: Dryophthoridae) is the most dangerous insect pest attacking palm trunks. Since this pest entered Egypt in 1922, the area of infection began to expand until it reached Upper Egypt, which is considered one of the date productions centers in Egypt (Saleh,

\footnotetext{
*Corresponding author: Mahmoud Abbas Ali

Email: m.abbas@agr.svu.edu.eg

Received: September 15, 2020.

Accepted: October 25, 2020.

Published: November 4, 2020.
}

1992; Ali et al., 2019). The insect have a complete development and the larva is the harmful stage, where it attacks the trunks of the palm trees and produces tunnels in them until they reach the head of the palm, which causes its death.(El-Mergawy, Al-Ajlan and A, 2011). Several studies have been conducted and others are underway to reduce and control the harm of this pest. Previous studies have adopted the use of chemical pesticides(Chihaoui-Meridja et al., 2020), plant essential oils(Ali et al., 2019), Microwave heating (Massa et al., 2019), pheromone traps (Mirzaei, 2019), and natural enemies such as mites(Allam and El-Badawy, 2017), nematodes (Chihaoui-Meridja et al., 2019), bacteria and fungi , (Malik et al., 2019). 
Plants contain reliable and effective substances in control of this pest along with other methods, especially to reduce the use of harmful chemical pesticides. Therefore, this study leads to evaluate and evaluate the efficiency of four plant extracts in their normal and nano form against both the egg and larva stages of RPW under lab conditions.

\section{Materials and Methods}

\section{Insect rearing}

The whole insects were collected from the infected palm trees at the research farm at the Faculty of Agriculture, South Valley University. The insects were reared under laboratory conditions at temperatures of $65 \%$ humidity for 8 consecutive generations. it was provided with strips of reeds of $10 \mathrm{~cm}$ length each day to obtain eggs and every 3 days to obtain larvae used in experiments

\section{Extraction preparation}

4 plants were used to obtain the extracts, namely eucalyptus (Eucalyptus globulus), Castor (Ricinus communis), Datura (Datura stramonium) and Oleander (Oleander nerium). The leaves of the plants were collected from the cultivated plants at South Valley University, Qena Campus, then transferred directly to the lab where they were dried in the shade for a week. Water extracts were made as follows for all plants. The leaves were grinded using a quick mixer to obtain the powder. 160 grams of powder was placed into 4 liters of distilled water to several cups listed $250 \mathrm{ml}$ capacity. The cups were placed in a hot water bath with a temperature of $50{ }^{\circ} \mathrm{C}$ for an hour, then transferred to the shaker for an hour and a half and then the result was filtered using filter paper in clean glass cups.

The filtrate was transferred to the crucible of the distillation apparatus where the water was disposed of until the powder was obtained at a temperature of $50{ }^{\circ} \mathrm{C}$ and the number of turns $200 \mathrm{rpm}$. The dry powder was removed from the crucible with a dedicated tool for that and was placed in dark packages until the used concentrations were used

\section{Extracts nanoparticles preparation}

Ball milling technique was used to prepare the four plant extracts nanoparticles. A $5 \mathrm{~g}$ charge of the used plant extracts particles were loaded into the ball milling flasks of the ball mills. In our experiments the used ball mills consist of a stainless-steel vial, this bottle is attached to a vibratory plate. A zirconium ball having a diameter of $3 \mathrm{~cm}$ repeatedly collides with the plate and powder inside the vial for 36 hours. The nano plant extracts were obtained after the end of the milling period

\section{Bioassay}

Aqueous instead of aquatic plant extracts were evaluated in their normal form and nanoparticles, both egg stage and first larval life.

\section{The ovicidal activity}

In an $11 \mathrm{~cm}$ diameter Petri dish 10 eggs were placed on filter paper, they were covered with another filter paper and $4 \mathrm{ml}$ of the extract solution was added and then the dish was covered and placed in incubation, 3 replicates were used for each concentration and 3 different concentrations for each plant extract (5, 10 and 15\%), the eggs were monitored periodically starting from the third day of the treatment, as were the observations and percentage of the eggs hatched, as well as eggs that did not hatch until the seventh day, which is a sufficient period for the natural hatching of eggs. The percent ovicidal activity was calculated using the following formula:

$$
\text { ovicidal activity }=\frac{\text { Numberofunhatchedeggs }}{\text { Totalnumberofeggsintroduced }} \times 100
$$




\section{Larvicidal activity}

The first instar larvae were evaluated using reed pieces as follows: The reeds stems were cut into small slices of $8 \mathrm{~cm}$ long and dipped in preprepared concentrations for 20 minutes. These treated pieces were presented to the larvae that were starved for 3 hours at a rate of 5 larvae per piece and were placed each two pieces in a petri dish below a filter paper, and duplicates were made for each concentration and 3 concentrations for each extract. The percentage of dead larvae that showed signs of inactivity was followed up and recorded.

\section{Experimental design}

A completely random design was used. Repeats and coefficients were randomly distributed among the experimental units used which were homogeneous in their number and age.

\section{Statistical analysis.}

The data related to non-hatching eggs, antifeedant, one-way ANOVA was used to analyze larvicidal activities. Duncan multiple range tests(Duncan, 1955) was used to determine the Significant differences between, the least significant difference (LSD) test was used to separate the mean values were significant at $95 \%$ level with SPSS software (version 25). ( $\mathrm{P} \leq 0.05)$. curves and the lethal concentrations $\left(\mathrm{LC}_{50}\right.$ and $\left.\mathrm{LC}_{90}\right)$ were obtained at $95 \%$ using probit analysis with LDP line software (Bakr, 2010).

\section{Results}

\section{The ovicidal activity}

The ovicidal activity of the four different used plant extracts in both Aqueous extract (group A) and aquatic nano extract (group B) is shown in Table (1-3) and Fig.(1and 2) The ovicidal activity was varied among and within the two different extracts groups. in general, the aquatic nano extract (group B) recorded the highest ovicidal activities compared to aquatic extract (group A). in aquatic extract (group A).The highest egg mortality was observed in extracts from datura, followed by extracts from eucalyptus, the aquatic extracts from datura caused the most diminished hatching rates $(66.67 \pm 0 \%)$ among the 4 plant extracts .while, in The aquatic nano extract (group B) the aquatic nano extract of eucalyptus recorded the highest ovicidal activity $(80.00 \pm 1.00 \%)$ followed by oleander nano extract $(76.67 \pm 0.58 \%)$, The egg hatchability after treatment with the three concentrations of the four plant extracts had significant effects between and within both $\mathrm{A}$ and $\mathrm{B}$ groups $(p<0.05)$, eucalyptus nano extract at $15 \%$ was the most active one followed by oleander nano extract at $15 \%$ and Datura normal extract at 15 , respectively.

\section{Larvicidal activity}

The results of current study presented in Table (4-6) and Fig.(3and 4) are clearly showed that all of the used extract was effective against the larvae in both of aquatic extract and at the aquatic nano plant extracts, Datura was the highest effect among all extraction in case of the aquatic extract, All the other extracts showed low or moderate larvicidal activities (Tables 3 and 4) .calculated $\mathrm{LC}_{50}$ and $\mathrm{LC}_{90}$ values of datura extract were 11.127 and $27.783 \mathrm{mg} / 100 \mathrm{ml}$. while eucalyptus was the highest effect among all extraction in case of the aquatic nano extract followed by Oleander, Datura, and Castor. calculated values of $\mathrm{LC}_{50}$ and $\mathrm{LC}_{90}$ for eucalyptus extract were 9.011 and $19.469 \mathrm{mg} / 100 \mathrm{ml}$. The larvae mortality had significant effects between and within both $\mathrm{A}$ and $B$ groups $(\mathrm{p}<0.05)$.

Further, it was noted that the RPW larvae were more sensitive than the eggs for extracts. 
Table 1: Percent ovicidal activity of plant aquatic and aquatic nano extracts against RPW eggs

\begin{tabular}{|c|c|c|c|c|c|c|}
\hline \multirow{2}{*}{$\begin{array}{c}\text { Extracts } \\
\text { type }\end{array}$} & \multirow{2}{*}{ Concentrations } & \multicolumn{4}{|c|}{ plant extracts } & \multirow[b]{2}{*}{ Control } \\
\hline & & Oleander & Eucalyptus & Datura & Castor & \\
\hline aquatic & $5 \%$ & $6.67 \pm 0.58^{\mathrm{hi}}$ & $13.33 \pm 0.58^{\mathrm{hi}}$ & $13.33 \pm 0.58^{\mathrm{hi}}$ & $13.33 \pm 0.58^{\mathrm{hi}}$ & 0 \\
\hline Nano & $10 \%$ & $33.33 \pm 0.58^{\mathrm{fg}}$ & $46.67 \pm 2.08^{\mathrm{ef}}$ & $43.33 \pm 0.58^{\mathrm{ef}}$ & $33.33 \pm 0.58^{\mathrm{fg}}$ & 0 \\
\hline extract & $15 \%$ & $50.00 \pm 1.00^{\mathrm{def}}$ & $60.00 \pm 1.00^{\text {bcde }}$ & $66.67 \pm 0.58^{\mathrm{abcd}}$ & $50.00 \pm 1.00^{\mathrm{def}}$ & 0 \\
\hline aquatic & $5 \%$ & $10.00 \pm 1.00^{\mathrm{hi}}$ & $16.67 \pm 1.53^{\mathrm{ghi}}$ & $20.00 \pm 0.00^{\mathrm{gh}}$ & $13.33 \pm 1.53^{\mathrm{hi}}$ & 0 \\
\hline Nano & $10 \%$ & $60.00 \pm 1.00^{\text {bcde }}$ & $56.67 \pm 0.58^{\text {cde }}$ & $53.33 \pm 0.58^{\text {cde }}$ & $43.33 \pm 1.15^{\mathrm{ef}}$ & 0 \\
\hline extract & $15 \%$ & $76.67 \pm 0.58^{\mathrm{ab}}$ & $80.00 \pm 1.00^{\mathrm{a}}$ & $70.00 \pm 1.00^{\mathrm{abc}}$ & $60.00 \pm 1.00^{\text {bcde }}$ & 0 \\
\hline \multicolumn{2}{|c|}{ L.S.D 0.05} & \multicolumn{5}{|c|}{3.146} \\
\hline \multicolumn{2}{|c|}{$\mathrm{F}_{0.05}$} & \multicolumn{5}{|c|}{0.000} \\
\hline
\end{tabular}

Table 2: Lethal concentrations of extracts against the eggs of RPW.

\begin{tabular}{ccccccccc}
\hline No & Extracts & LC50 & Lower limit & Upper limit & Index & RR & Slope +/- & LC90 \\
\hline 1 & Datura & 11.127 & 9.077 & 14.696 & 100 & 0.766 & $3.225 \pm 0.783$ & 27.783 \\
2 & Eucalyptus & 11.611 & 9.282 & 16.568 & 95.832 & 0.799 & $2.872 \pm 0.765$ & 32.448 \\
3 & Oleander & 14.528 & 11.611 & 23.939 & 76.59 & 1 & $3.111 \pm 0.857$ & 37.51 \\
4 & Castor & 15.116 & 11.84 & 36.99 & 73.611 & 1.04 & $2.325 \pm 0.773$ & 53.778 \\
\hline
\end{tabular}

Index compared with datura Resistance Ratio (RR) compared with oleander

Table 3: Lethal concentrations of nano extracts against the eggs of RPW.

\begin{tabular}{ccccccccc}
\hline No & Nano Extracts & LC $_{50}$ & Lower limit & Upper limit & Index & RR & Slope $+/-$ & LC90 \\
\hline 1 & Eucalyptus & 9.011 & 7.399 & 10.835 & 100 & 0.951 & $3.785 \pm 0.783$ & 19.649 \\
2 & Oleander & 9.48 & 7.971 & 11.232 & 95.053 & 1 & $4.247 \pm 0.826$ & 18.994 \\
3 & Datura & 9.652 & 7.56 & 12.584 & 93.359 & 1.018 & $2.878 \pm 0.738$ & 26.907 \\
4 & Castor & 11.921 & 9.528 & 17.347 & 75.589 & 1.257 & $2.864 \pm 0.77$ & 33.403 \\
\hline
\end{tabular}

Index compared with Eucalyptus Resistance Ratio (RR) compared with Oleander
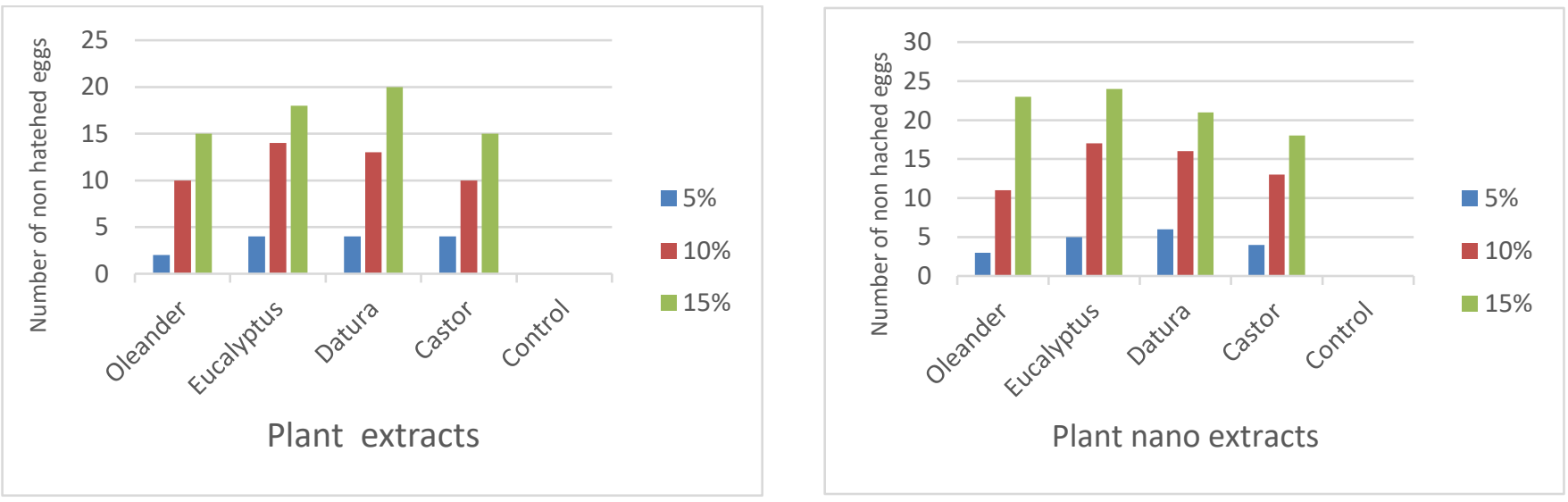

Figure 1Percent ovicidal activity of plant aquatiEigure 2Percent ovicidal activity of plant aquatic extracts against RPW eggs. nano extracts against RPW 
Ali et al., SVU-International Journal of Agricultural Sciences, 2 (2): 306-315, 2020

Table 4: Percent larvicidal activity of plant aquatic and aquatic nano extracts against RPW larvae

\begin{tabular}{|c|c|c|c|c|c|c|}
\hline \multirow{2}{*}{$\begin{array}{c}\text { Extracts } \\
\text { type }\end{array}$} & \multirow{2}{*}{ Concentrations } & \multicolumn{4}{|c|}{ plant extracts } & \multirow[b]{2}{*}{ Control } \\
\hline & & Oleander & Eucalyptus & Datura & Castor & \\
\hline \multirow{3}{*}{$\begin{array}{c}\text { aquatic } \\
\text { Nano } \\
\text { extract }\end{array}$} & $5 \%$ & $40.00 \pm 1.00^{\mathrm{hi}}$ & $50.00 \pm 1.37^{\text {fgh }}$ & $30.00 \pm 0.00^{\mathrm{i}}$ & $43.33 \pm 0.58^{\mathrm{ghi}}$ & 0 \\
\hline & $10 \%$ & $56.67 \pm 0.58^{\mathrm{efg}}$ & $73.33 \pm 1.53^{\mathrm{cd}}$ & $63.33 \pm 0.00^{\mathrm{def}}$ & $66.67 \pm 0.58^{\text {cde }}$ & 0 \\
\hline & $15 \%$ & $80.00 \pm 1.73^{\mathrm{bc}}$ & $93.33 \pm 0.58^{\mathrm{ab}}$ & $90.00 \pm 1.00^{\mathrm{ab}}$ & $90.00 \pm 0.58^{\mathrm{ab}}$ & 0 \\
\hline \multirow{3}{*}{$\begin{array}{l}\text { aquatic } \\
\text { Nano } \\
\text { extract }\end{array}$} & $5 \%$ & $70.00 \pm 0.58^{\text {cde }}$ & $60.00 \pm 0.00^{\mathrm{def}}$ & $60.00 \pm 0.00^{\mathrm{def}}$ & $70.00 \pm 0.00^{\text {cde }}$ & 0 \\
\hline & $10 \%$ & $100.00 \pm 0.00^{\mathrm{a}}$ & $93.33 \pm 0.58^{\mathrm{ab}}$ & $90.00 \pm 0.58^{\mathrm{ab}}$ & $100.00 \pm 0.00^{\mathrm{a}}$ & 0 \\
\hline & $15 \%$ & $100.00 \pm 0.00^{\mathrm{a}}$ & $100.00 \pm 0.00^{\mathrm{a}}$ & $100.00 \pm 0.00^{\mathrm{a}}$ & $100.00 \pm 0.00^{\mathrm{a}}$ & 0 \\
\hline \multicolumn{2}{|c|}{ L.S.D 0.05} & \multicolumn{5}{|c|}{2.567} \\
\hline \multicolumn{2}{|r|}{$\mathrm{F}_{0.05}$} & \multicolumn{5}{|c|}{0.000} \\
\hline
\end{tabular}

Table 5: Lethal concentrations of extracts against the RPW larvae

\begin{tabular}{ccccccccc}
\hline No & Extracts & LC $_{50}$ & Lower limit & Upper limit & Index & RR & Slope +/- & LC90 \\
\hline 1 & Eucalyptus & 5.228 & 2.844 & 6.77 & 100 & 0.747 & $2.836 \pm 0.77$ & 14.8 \\
2 & Castor & 6.042 & 3.7 & 7.681 & 86.528 & 0.863 & $2.787 \pm 0.742$ & 17.421 \\
3 & Oleander & 7.003 & 5.6 & 7.4 & 74.654 & 1 & $2.151 \pm 0.704$ & 27.611 \\
4 & Datura & 7.431 & 5.743 & 8.97 & 70.354 & 1.061 & $3.51 \pm 0.761$ & 17.226 \\
\hline
\end{tabular}

Index compared with Eucalyptus $\quad$ Resistance Ratio (RR) compared with Datura

Table 6: Lethal concentrations of nano extracts against the RPW larvae

\begin{tabular}{ccccccccc}
\hline No & Nano Extracts & LC $_{50}$ & Lower limit & Upper limit & Index & RR & Slope $+/-$ & LC 90 \\
\hline 1 & Castor & 3.202 & 2.127 & 6.123 & 100 & 0.763 & $2.751 \pm 1.04$ & 9.363 \\
2 & Oleander & 3.273 & 3.232 & 6.693 & 97.831 & 0.779 & $2.924 \pm 0.965$ & 8.978 \\
3 & Eucalyptus & 4.195 & 2.184 & 5.435 & 76.329 & 0.999 & $3.619 \pm 0.969$ & 9.482 \\
4 & Datura & 4.199 & 2.068 & 5.516 & 76.256 & 1 & $3.366 \pm 0.915$ & 10.09 \\
\hline
\end{tabular}

Index compared with Castor Resistance Ratio (RR) compared with Datura

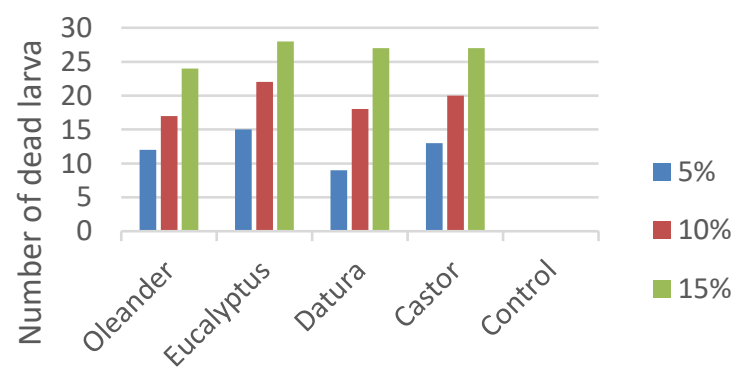

Plant extracts

Figure 3Percent laravacidal activity of plant aquatic extracts against RPW.

\section{Discussion}

Since the end of the $20^{\text {th }}$ century, RPW began to spread till it reached most of the Arab Gulf countries like the United Arab Emirates and Saudi Arabi, and entered Egypt till it became the most dangerous pest for palm at all (Saleh, 1992). Scientists and researchers seek out safe and effective ways and means that cut back the

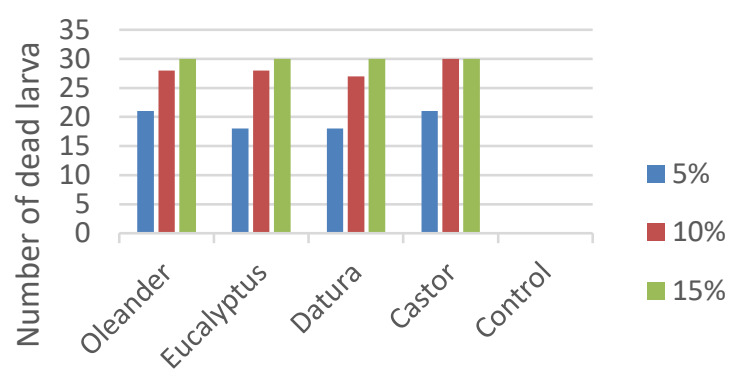

Plant nano extracts

Figure 4Percent of larvicidal activity of plant nano extracts against RPW

harmful effects of this devastating weevil on the palm trees in Egypt and all over the world.

Among the active substances in combating this pest is the use of plant materials such as oils and extracts. For this study, the plant extracts of the four plants used proved effective against both eggs and larvae, and the activity of these 
extracts increased in the form of nano. The results indicated that there were significant differences among the used treatments and concentrations. These findings are in agreement with previous studies where castor have been proved to have insecticidal activities against, peach fruit flies (Ali, 2018), RPW,(Ali et al., 2019) Maconellicoccus hirsutus (Holtz et al., 2019), The toxic activity of castor is probably due to the presence of its major active components such as :the alkaloid ricinine, Nmethyl ricinine and the ricin protein, which are toxic substances in the leaves. (Worbs et al., 2011; Fallström, 2014; Polito et al., 2019), these active components cause reduction in all types of hemocytes and plasmocytes, it decreased carbohydrate content, (Ali and Ibrahim, 2018).

Datura has been shown to be effective as natural pesticides against several insect pests, D. stramonium was used as mosquito repellent, (Spring et al., 2016), it showed remarkable insecticidal efficacy against the rice weevil, Sitophilus oryzae , (Jawalkar et al., 2016).aqueous extracts of D. stramonium showed significantly the efficacy against some insect pests of cowpea,(Adesina and Enudeme, 2018; Obadofin et al., 2018). Also, it had larvicidal activity against greater wax moth Galleria mellonella (Soliman et al., 2019) and had high oviposition deterrence activity housefly at (Attaullah et al., 2020). The effective effect of the datura is due to its active substances, especially its content from alkaloids toxins including atropine, hyoscyamine and scopolamine, found to having anticholinergic and Broncho dilating activity. Both Atropine and scopolamine. Both Atropine and scopolamine block the muscarinic receptors , (Gaire and Subedi, 2013), 4,8dimethyl-3,8-dien-2-one (11.2\%), citral $(26.5 \%)$, geraniol $(10.5 \%)$ and sesquirosefuran (11.1\%) (Aboluwodi et al., 2017).
Eucalyptus had an insecticidal against activity against wide range of insect pests, peach fruit fly (Ali, 2018), Tribolium castaneum (Herbst) (Ahmad et al., 2019) and RPW (Ali et al.). The botanical activity of eucalyptus oils return to its major contents like 1,8-cineole, limonene, linalool, a-pinene, and a-terpineol, (Batish et al., 2008; Noumi et al., 2011), 1,8-Cineole, leading to damaged structural stability of the cell, leading successively to increased permeability(Verma et al., 2017). These components acted on AChE and octopamine receptors, (Castillo-Morales et al., 2019), and 1.8-cineol It can act as an antagonist to histamine receptors, (Beer et al., 2017).

Insecticidal activity of $N$. oleander has long been recognized, the insecticidal principles of the leaves are their cardenolides such as cardiac glycosides kaneroside, alpha -L-olendroside $5 \alpha$-adynerin ,digitoxigenin, neriumoside and other lycosides.(Rajendra et al., 2013), flavonoids and phenolics, showed strong antioxidant and antimicrobial activities, (Einali et al., 2018). trypsin inhibitors, oxalates alkaloids, cardiac glycosides, cyanogenic glycosides, phytates, haemagglutinins (lectins), saponins, tannins, and gossypol, (Kgosana, 2019). With cardiac glycosides, digitoxigenin, oleandine, olandroside, neuroside, theftin, and theftoxin, being the active ingredients, they work to block the potassium and sodium pumps in the muscle cells, and this property makes them harmful to the heart. (Ershad, 2018), Cardiac glycosides (CGs), especially oleangins, are found within the plant. It is possible that CG affects the heart as it can damage the activity of the ATPase pump as well as the sodium-potassium (NKA) pump, resulting in positive inotropia. As for OLE, it leads to electromechanical disturbances in the heart as a result of inhibition of the $\mathrm{Na}+/ \mathrm{K}+$ pump, in addition to mitochondrial swelling, as well as modulation of the plasma (endo) $\mathrm{Ca} 2+$ 
ATPase without affecting the autonomic nervous system,(Botelho et al., 2017).flower extracts of Nerium oleander found to have larvicidal activity against the larval stage of Anopheles stephensi and Aedes aegypti, Culex quinquefasciatus,(Raveen et al., 2017), Hydroethanolic extracts of $N$. oleander found to own a toxic effect against Pectinophora gossypiella (Suanders).(Moustafa, Al Shater and Yousef, 2018)

The use of nanotechnology increases the efficiency of the plant materials, as it provides an increase in the surface of the particles, thus increasing its activity towards the target pests. Eucalyptus oil with nano capsules found to have repellent effect against horn fly in low dose, (Galli et al., 2018), it also has an insecticidal activity against Myzus persicae (Khoshraftar et al., 2019). (Adak et al., 2020), It was concluded that nano emulsions made from eucalyptus showed a remarkable superiority over eucalyptus oil and thus they were recommended against rice storage bugs, S. oryzae and T. castaneum.

\section{Conclusion}

Plant extracts provide a good source for the materials used in the control of the red palm weevil because it contains effective substances against eggs and larvae, and can be relied upon in integrated control programs as well as other control methods with the necessity to use the ideal method for applying these materials in the infested palms.

\section{Acknowledgements}

The authors are grateful to Valley University; Egypt for providing Financial support. All thanks to prof. dr / Khaled Ebn El El-Walid From the Department of Physics, College of Science, for his support and preparation of nanomaterials

\section{Conflict of interest}

The authors hereby declare that no competing and conflict of interests exist.

\section{References}

Aboluwodi, A. S., Avoseh, N., Lawal, A., Ogunwande, I. and Giwa, A. J. J. o. M. P. S. (2017) 'Chemical constituents and anti-inflammatory activity of essential oils of Datura stramonium L', 5, pp. 2125.

Adak, T., Barik, N., Patil, N. B., Govindharaj, G.-P.-P., Gadratagi, B. G., Annamalai, M., Mukherjee, A. K. and Rath, P. C. (2020) 'Nanoemulsion of eucalyptus oil: An alternative to synthetic pesticides against two major storage insects (Sitophilus oryzae (L.) and Tribolium castaneum (Herbst)) of rice', Industrial Crops and Products, 143, pp. 111849.

Adesina, J. and Enudeme, D. J. G. (2018) 'Insecticidal Efficacy of Some Plant Aqueous Extracts Mixtures against Post Flowering Insect Pest of Cowpea', 18, pp. 22nd.

Ahmad, F., Iqbal, N., Zaka, S. M., Qureshi, M. K., Saeed, Q., Khan, K. A., Ghramh, H. A., Ansari, M. J., Jaleel, W. and Aasim, M. J. S. j. o. b. s. (2019) 'Comparative insecticidal activity of different plant materials from six common plant species against Tribolium castaneum (Herbst)(Coleoptera: Tenebrionidae)', 26(7), pp. 1804-1808.

Ali, A. M. and Ibrahim, A. M. A. (2018) 'Castor and camphor essential oils alter hemocyte populations and induce biochemical changes in larvae of Spodoptera littoralis (Boisduval) (Lepidoptera: Noctuidae)', Journal of Asia-Pacific Entomology, 21(2), pp. 631-637.

Ali, M. (2018) 'Toxicity of certain plant oils on pupil stage of the peach fruit fly, $B$. 
zonata (sunders) (Tephritidae:

Diptera)", 8(6), pp. 372-374.

Ali, M., Mohanny, K. M., Mohamed, G. S. and Allam, R. O. H. (2019) 'Efficacy of some promising plant essential oils to control the red palm weevil Rhynchophorus ferrugineus olivier (coleoptera: curculionidae) under laboratory conditions \% $\mathrm{J}$ SVUInternational Journal of Agricultural Sciences', 1(2), pp. 12-45.

Allam, S. F. and El-Badawy, A. R. 'Mass production of the facultative parasitic mite, Aegyptus rhynchophorus, as a natural enemy against the red palm weevil in Egypt'. Proceedings of the VIII International Scientific Agriculture Symposium, Jahorina, 5-8.

Attaullah, Zahoor, M. K., Zahoor, M. A., Mubarik, M. S., Rizvi, H., Majeed, H. N., Zulhussnain, M., Ranian, K., Sultana, K., Imran, M. and Qamer, S. (2020) 'Insecticidal, biological and biochemical response of Musca domestica (Diptera: Muscidae) to some indigenous weed plant extracts', Saudi Journal of Biological Sciences, 27(1), pp. 106-116.

Bakr, E. J. U. h. w. e. c. 1. (2010) 'LDP Line software'.

Batish, D. R., Singh, H. P., Kohli, R. K., Kaur, S. J. F. E., and Management (2008) 'Eucalyptus essential oil as a natural pesticide', 256(12), pp. 2166-2174.

Beer, A., Sagorchev, P., Uzunova, J. and Lukanov, J. J. S. J. o. P. P. (2017) 'Effects of 1.8-cineol (eucalyptol) on the Activity of Histamine H1 Receptors', SciFed Journal of Plant Physiology, 1(1).

Botelho, A. F. M., Santos-Miranda, A., Joca, H. C., Mattoso, C. R. S., de Oliveira, M. S., Pierezan, F., Cruz, J. S., Soto-Blanco,
B. and Melo, M. M. J. J. o. e. (2017) 'Hydroalcoholic extract from Nerium oleander L.(Apocynaceae) elicits arrhythmogenic activity', 206, pp. 170177.

Castillo-Morales, R. M., Otero, A. L. C., Mendez-Sanchez, S. C., Da Silva, M. A. N., Stashenko, E. E., Duque, J. E. J. C. B., Toxicology, P. P. C. and Pharmacology (2019) 'Mitochondrial affectation, DNA damage and AChE inhibition induced by Salvia officinalis essential oil on Aedes aegypti larvae', 221, pp. 29-37.

Chihaoui-Meridja, S., Abbes, K., Harbi, A., La, A., Pergola, P. S. and Chermiti, B. (2019) 'Assessment of selected biological traits of the red palm weevil Rhynchophorus ferrugineus (Olivier, 1790) reread on apple and efficacy evaluation of thiamethoxam and emamectine benzoate for its control'. Journal of Entomology and Zoology Studies 7(5): 1390-1396

Chihaoui-Meridja, S., Harbi, A., Abbes, K., Chaabane, H., La Pergola, A., Chermiti, B. and Suma, P. (2020) 'Systematicity, persistence and efficacy of selected insecticides used in endotherapy to control the red palm weevil Rhynchophorus ferrugineus (Olivier, 1790) on Phoenix canariensis', Phytoparasitica, 48(1), pp. 75-85.

Duncan, D. J. B. (1955) 'Multiple Ranges and Multiple F. test Biometrics', 11, pp. 1 citation_lastpage $=42$.

Einali, A., Azizian-Shermeh, O., Ghasemi, A. J. J. o. F. M. and Characterization (2018) 'Phytochemical screening and antimicrobial activities of Periploca aphylla Decne, Persian walnut (Juglans regia L.) and oleander (Nerium indicum Mill.) Leaf extracts', 12(2), pp. 13501359. 
El-Mergawy, R., Al-Ajlan, A. J. J. o. A. S. and A, T. (2011) 'Red palm weevil, Rhynchophorus ferrugineus (Olivier): economic importance, biology, biogeography and integrated pest management', 1, pp. 1-23.

Ershad, M. J. V. J. o. E. M. (2018) 'Nerium oleander-A common poisonous garden plant', 13, pp. 68-69.

Fallström, S. (2014) 'Ricinus communis L. varietes: Taxonomical description'. Helsingfors universitet. master's thesis.

FAO (2019) 'Data for Crop Production in 2017 (accessed on 25/1/2019)

http://www.fao.org/faostat/en/\#da

Gaire, B. P. and Subedi, L. (2013) 'A review on the pharmacological and toxicological aspects of Datura stramonium L', Journal of Integrative Medicine, 11(2), pp. 73-79.

Galli, G. M., Roza, L. F., Santos, R. C., Quatrin, P. M., Ourique, A. F., Klein, B., Wagner, R., Baldissera, M. D., Volpato, A. and Campigotto, G. J. J. o. e. e. (2018) 'Low Dose of Nanocapsules Containing Eucalyptus Oil Has Beneficial Repellent Effect Against Horn Fly (Diptera: Muscidae)', 111(6), pp. 2983-2987.

Holtz, A. M., de Carvalho, J. R., da Silva Gomes, M., Neto, V. B., Piffer, A. B. M. and Aguiar, R. L. J. J. o. E. A. I. (2019) 'Toxicity Aqueous Extract of Castor Bean (Ricinus communis) to Maconellicoccus hirsutus (Green)(Hemiptera: Pseudococcidae)', pp. 1-6.

Jawalkar, N., Zambare, S., Zanke, S. J. J. o. E. and Studies, Z. (2016) 'Insecticidal property of Datura stramonium L. seed extracts against Sitophilus oryzae
L.(Coleoptera: Curculionidae) in stored wheat grains', 4, pp. 92-96.

Kgosana, K. G. J. T. O. j. o. v. r. (2019) 'The effects of extraction techniques and quantitative determination of oxalates in Nerium oleander and feeds', 86(1).

Khoshraftar, Z., Safekordi, A. A., Shamel, A., Zaefizadeh, M. J. G. C. L. and Reviews (2019) 'Synthesis of natural nanopesticides with the origin of Eucalyptus globulus extract for pest control', 12(3), pp. 286-298.

Malik, M., Ahmad, S., Ahmad, J., Abbasi, A., Sufyan, M. and Arif, M. J. A. E. (2019) 'Efficacy of Bacillus thuringiensis and Beauveria bassiana against red palm weevil Rhynchophorus ferrugineus Olivier (Coleoptera: Curculionidae)', 27(2), pp. 386-394.

Massa, R., Panariello, G., Migliore, M., Pinchera, D., Schettino, F., Griffo, R., Martano, M., Power, K., Maiolino, P. and Caprio, E. J. J. o. P. P. (2019) 'Research Paper (Control: Insects) Microwave heating: a promising and eco-compatible solution to fight the spread of red palm weevil', 37(2), pp. 143-148.

Mirzaei, M. (2019) 'Effect of different kairomons on aggregation pheromone in mass trapping operation of red palm weevil. ', Phys. Rev. 47, 777-780.

Moustafa, H. Z., Al Shater, H. and Yousef, H. J. I. J. A. R. B. S. (2018) 'Toxicity of Nerium oleander extracts against Pectinophora gossypiella (Saunders) (Lepidoptera: Gelechiidae)', 5(3), pp. 163-168.

Noumi, E., Snoussi, M., Hajlaoui, H., Trabelsi, N., Ksouri, R., Valentin, E. and Bakhrouf, A. J. J. o. M. P. R. (2011) 'Chemical composition, antioxidant and antifungal potential of Melaleuca 
alternifolia (tea tree) and Eucalyptus globulus essential oils against oral Candida species', 5(17), pp. 4147-4156.

Obadofin, A., Fatoba, T., Owolabi, D., Yakubu, B. J. J. o. E. I. and Countries, A. i. D. (2018) 'Comparative Effects of Aqueous Leaves Extracts of Selected Plants Material on Insect Pest of Cowpea (Vigna Unguiculata L. Walp)', 10(1).

Polito, L., Bortolotti, M., Battelli, M. G., Calafato, G. and Bolognesi, A. J. T. (2019) 'Ricin: An Ancient Story for a Timeless Plant Toxin', 11(6), pp. 324.

Rajendra, D. C., Asma, P. B., Jayprakash, S. S., Meena, J. K., Pournima, S. S. J. I. J. o. P. T. and Practices (2013) 'Phytochemical Screening and Antibacterial Activity of Nerium Indicum Leaves', 4(3), pp. 1-4.

Raveen, R., Pandeeswari, M., Ahmed, F., Reegan, D., Samuel, T., Arivoli, S. and Jayakumar, M. J. I. J. o. M. R. b. (2017) 'Bioefficacy of Nerium oleander Linnaeus (Apocynaceae) floral extracts on the larva of three vector mosquitoes of medical importance', 4(6), pp. 65-77.

Saleh, M. 1992. Red palm weevil, Rhyncbophours ferrugineus (Olivier) is first recorded for Egypt and indeed the African continent. List10634.

Soliman, M. M., Mohanna, K. M., Mansour, H. and enaim Seddik, M. A. J. S.-I. J. o. A. S. (2019) 'Effect of some plant extracts on greater wax moth Galleria mellonella L', 1(2), pp. 1-11.

Spring, P., Nagar, S., Ramteke, P. W. and Ross, E. M. 2016. Biological Activities of Solanaceous Plants Against Vector Mosquitoes: A Review. In 5th International Conference on Innovative Research in Engineering Science and Management (ICIRESM-16)
Verma, R. S., Joshi, N., Padalia, R. C., Goswami, P., Singh, V. R., Chauhan, A., Verma, S. K., Iqbal, H., Verma, R. K., Chanda, D. J. I. c. and products (2017) 'Chemical composition and allelopathic, antibacterial, antifungal and in vitro acetylcholinesterase inhibitory activities of yarrow (Achillea millefolium L.) native to India', Industrial Crops and Products 104, pp. 144-155.

Worbs, S., Köhler, K., Pauly, D., Avondet, M.A., Schaer, M., Dorner, M. B. and Dorner, B. G. J. T. (2011) 'Ricinus communis intoxications in human and veterinary medicine - a summary of real cases', Toxins 3(10), pp. 13321372. 